LAW, ETHICS, AND MEDICINE

\title{
Creating and sacrificing embryos for stem cells
}

\author{
K Devolder
}

J Med Ethics 2005;31:366-370. doi: 10.1136/jme.2004.008599

The compromise position that accepts the use and derivation of stem cells from spare in vitro fertilisation embryos but opposes the creation of embryos for these purposes is a very weak ethical position. This paper argues that whatever the basis is on which defenders of this viewpoint accord intrinsic value to the embryo, once they accept the creation and sacrifice of embryos to benefit infertile people with a child-wish, they do not have a sound moral argument to condemn the creation and sacrifice of embryos to benefit ill and injured people.

Correspondence to: K Devolder, Centre for Environmental Philosophy and Bioethics, Ghent University, Belgium: katrien.devolder@ugent.be

Received 2 March 2004 In revised form 5 April 2004 Accepted for publication 16 June 2004
O ne of the central questions in the current stem cell debate is whether human embryonic stem cell research (ESCR) should be allowed, and, if so, under what constraints. Discussions about the regulation of ESCR are a stumbling block in developing stem cell policy. On the one hand there is a growing consensus that of all types of stem cell, the embryonic stem cells hold most promise for particular and important therapeutic and research aims. ${ }^{1}$ On the other hand, there is the controversial issue of "killing" human embryos through stem cell derivation.

Most of the participants in the stem cell debate, and especially those who are involved in policy making, opt for one of the possible compromise positions. They do not want to block human ESCR, but attempt to articulate at least some grounds for restraint in the use and derivation of embryonic stem cells (ESCs) in order to protect the embryo. I will focus on the compromise position that accepts the use and derivation of stem cells from spare in vitro fertilisation (IVF) embryos that are no longer needed in a procreation project, but opposes the creation of embryos solely for the purpose of stem cell derivation, the so-called "research embryos". Many European advisory and regulatory bodies defend this position ${ }^{2}$ and a survey of public attitudes in nine European Union countries has shown that the majority of the participants in this research project also share this viewpoint. ${ }^{3}$

THE DISCARDED-CREATED DISTINCTION I will argue that this position, which is grounded on the moral distinction between the use of spare embryos for research and therapy and the creation of research embryos-the so-called "discarded-created distinction" (from now on DCD) - is a very weak position. The main reason is the inconsistency between the "revealed" beliefs (that is, beliefs revealed by one's acts or omissions) of its defenders and their professed beliefs. I will argue that whatever the basis is on which defenders of this viewpoint accord intrinsic value to the embryo, once they accept the creation and sacrifice of embryos to benefit infertile people with a child-wish, they do not have a sound reason to condemn the creation and sacrifice of embryos to benefit ill and injured people. Furthermore, I will show that an approach to ESCR which would also allow the creation of embryos solely for the derivation of stem cells would be more compatible with the revealed beliefs of those who currently defend DCD, and with widely shared values, in particular the alleviation of individual human suffering.

\section{ARGUMENTS IN FAVOUR OF DERIVING STEM CELLS FROM SPARE EMBRYOS}

Defenders of DCD find the use and derivation of stem cells from spare IVF embryos ethically acceptable but not the creation of research embryos for these purposes. The latter could be created by IVF but could also be the result of somatic cell nuclear transfer (SCNT) $)^{5}$ or embryo splitting. Let us examine the arguments underlying this position.

First we have to ask ourselves why the defenders of DCD want some human ESCR to go forward. Why do they accept the use and derivation of stem cells from spare IVF embryos?

Their motivation is grounded on one or a combination of the following widely accepted principles. Among these are the principle of freedom of research ${ }^{6}$ and the principle of progress, ${ }^{7}$ which state that restraints on scientific research are inherently offensive and generally unjustifiable $^{8}$ and that we have a right to acquire new knowledge. The principles of beneficence and non-maleficence ${ }^{9}$ state that it is right to benefit people if we can, and wrong to harm them. ESCR could provide knowledge and therapies that would benefit thousands of people. Another principle referred to by defenders of DCD is the principle of proportionality, ${ }^{10}$ which states that the research has to serve an important purpose, such as a major health interest. In its recommendations on stem cell research, the US National Bioethics Advisory Commission (NBAC) expressed it this way: "In our view, the potential benefits of the research outweigh the harms of the embryos that are destroyed in the research process" ${ }^{\prime 1}{ }^{11}$ Another principle used to defend DCD is the principle of subsidiarity, ${ }^{12}$ which states that we have to choose the less contentious means of achieving the intended goal. Defenders of DCD apparently consider spare embryos as a necessary and also a sufficient stem cell source to reach the intended 
research goals. However, as John Harris has pointed out, ${ }^{13}$ the most important principle in defence of the use of spare embryos for research is the principle of waste avoidance, which states that, other things being equal, it must be better to make good use of something than to allow it to be wasted. With regard to ESCR the argument goes that spare embryos are going to be destroyed anyway because they are no longer needed in a procreation project, and that it is better to use them for a greater good-that is, for research and therapies. After all, it does not alter their final disposition.

Many people would agree that these are all valuable principles. ${ }^{14}$ Of course it is better to benefit people than to cause them harm, and of course the research has to serve important purposes and valuable things should not be wasted. None of these principles, however, suffices to justify DCD. They express why one wants some ESCR to go forward, and why one supports the use and derivation of stem cells from spare embryos, but it does not follow from these principles why one opposes the creation of research embryos. It is, for example, perfectly possible to argue against the waste of spare embryos while at the same time considering the creation of research embryos as ethically acceptable.

The relevant question here is what exactly makes it unethical to create embryos solely for research. Why is the use and derivation of embryonic stem cells from research embryos "ethically worse" than from spare embryos, and this to a degree that justifies the prohibition of the creation of research embryos?

\section{ARGUMENTS AGAINST THE CREATION OF RESEARCH EMBRYOS \\ Instrumentalisation of the embryo}

The principal objection of advocates of DCD to the creation of research embryos is that through this act the embryo is not treated with the appropriate respect such a form of human life is entitled to, because it is used merely as a means to an end. The underlying idea is that respect for human beings prevents the instrumental use of embryos, ${ }^{15}$ an act that, according to some, violates "human dignity". ${ }^{16}$

Most advocates of DCD genuinely think the embryo deserves "special" respect. They consider it to be more valuable than any other human cell or tissue. However, by accepting the creation of spare embryos and their use for research, they apparently believe that its right to life can be weighed up against other values and interests and that human dignity is not violated per se by using early embryos as a means for research.

This raises the following question: if defenders of DCD do not consider the embryo as a person and accept the creation and sacrifice of embryos to help infertile people and their use for research, should they not also accept the creation and sacrifice of embryos to help to cure ill and injured people? After all, in both cases embryos are created as a means to alleviate human suffering and increase human wellbeing. Apparently, the argument of instrumentalisation alone does not suffice to justify DCD. It is not a logical consequence that one opposes the creation of research embryos. One can agree that the embryo is instrumentalised in an IVF treatment or in embryo research without disapproving of this.

Defenders of DCD reply to this that what makes the difference, in other words, what justifies DCD is that creating research embryos involves a "distinct kind of exploitative attitude, reflecting the thought that an embryo is something whose entire significance may be characterized by the external purposes for which we brought it into existencethe clearest possible case of treating something as a 'mere means ${ }^{\prime \prime} .{ }^{17}$ A related argument was expressed by the NBAC in their 1999 report on stem cell research: "the act of creating an embryo for reproduction is respectful in a way that is commensurate with the moral status of embryos, while the act of creating an embryo for research is not". ${ }^{18}$

But what is meant by "respectful in a way that is commensurate with the moral status of an embryo"? And why does the creation of research embryos involve a "distinctive kind of exploitative attitude"? Let us investigate these arguments and see whether they can justify DCD.

\section{Creation of research embryos is not commensurate with the moral status of the embryo}

Here we first have to ask ourselves which moral status defenders of DCD accord to the human embryo. The fact that they accept "destructive" embryo research shows that they do not consider the embryo as a person and even do not accord a moral status to it close to that of a person. Nevertheless, they believe it has intrinsic value-value independent of people's intentions-and, therefore, merits "special respect".

Some say the embryo has intrinsic value because it possesses human dignity. ${ }^{19}$ We should note here that there is no agreement on the meaning of "human dignity". It is a vague expression that has to be clarified when used as an argument. Moreover, defenders of DCD apparently think that the fact that embryos possess human dignity does not imply that we have to protect them under all circumstances. After all, they accept the creation and sacrifice of spare IVF embryos. Consequently, the mere reference to human dignity cannot justify DCD.

Some say the embryo has to be protected because it has symbolic value. The European Society for Human Reproduction and Embryology, for example, stated that "the pre-implantation embryo is human and deserves our respect as a symbol of future human life ${ }^{\prime \prime} .{ }^{20}$ In symbolic issues like this, however, it is not really the embryo that is at issue, but the impact of certain practices on our respect for human life. The relevant question here is whether the creation of research embryos will weaken our communal respect for human life in some way that IVF or the experimental use of spare embryos does not. There is nothing to suggest that this will be the case. ${ }^{21}$ Consequently, referring to symbolic value is not a sufficient argument to justify DCD. But taking into consideration the question of what the embryo is a symbol of brings us to a viewpoint on the embryo that most, if not all, defenders of DCD (implicitly) share. Therefore, this viewpoint is also more conducive to finding another valuable approach to ESCR that is more compatible with the revealed beliefs of defenders of DCD.

This widely shared viewpoint forms the basis of the Dutch Embryo $\mathrm{Act}^{22}$ and is expressed by the Health Council of the Netherlands as follows: "since it is human in origin and has the potential to develop into a human individual, the embryo has intrinsic value on the basis of which it deserves respect". ${ }^{23}$ The French National Consultative Ethics Committee defends the position that "the embryo or foetus has the status of a potential human being who must command universal respect". ${ }^{24}$ Both advisory bodies defend DCD and both believe the embryo has intrinsic value because it is a potential human being, a potential person. There exist, of course, various interpretations of the concept of "potentiality", but it is not the aim of this paper to analyse these various views. I treat them elsewhere. ${ }^{25}$ The point to note is that whatever the criteria of potentiality are on which defenders of DCD attribute an intrinsic moral status to the embryo, they cannot explain the difference in moral status between spare and research embryos. Both have (or have not) the "intrinsic capacity" to develop into a person because of their genetic constitution and other characteristics of the embryo itself, and in both cases this capacity, this potentiality, will be frustrated when they are used for research. 
Consequently, with regard to their intrinsic status-that is, their value in themselves, independent of people's intentions-there is no moral difference between spare and research embryos. So what can it mean if one says that the creation of spare embryos is more commensurate with the moral status of embryos?

\section{Parental project}

The following consideration may establish a large consensus among those who consider the creation and "killing" of spare embryos as ethically acceptable. Whatever the human emotions and opinions in relation to the embryo or the fetus may be, as soon as it becomes a question of the procreation project, the embryo is experienced as "the expected child" from the moment a woman knows she is pregnant or, in case of IVF, the embryo is created in vitro. ${ }^{26}$

The value people who undergo an IVF treatment ascribe to the in vitro embryo is variable and rises considerably as soon as the embryo is actually used in a parental project and decreases when it is no longer used in such a project. It is then referred to as "spare", "surplus" or "supernumerary". One of three options for the conceivers or the "owners" of spare embryos is to donate those of good quality to another couple (in which case they will not be considered as "spare" anymore, because they are again included in a procreation project), but most of them will be donated for research or will be discarded. ${ }^{27}$ Many people even forget that a number of their embryos are still frozen or do not even answer fertility clinics when asked what should be done with their surplus embryos. ${ }^{28}$ And in some countries with restrictive regulations, such as Germany and Austria, spare embryos can be cryopreserved for no more than one year. If, by then, they are not used for reproductive purposes by their conceivers, they must be destroyed.

Apparently, people who undergo IVF treatment and those who accept these practices believe that not every embryo's intrinsic potential to become a person must be realised. The embryo as such is not the object of great value and almost absolute protection, but the embryo that is intended to lead to the birth of a desired child. Not only couples or individuals who create spare embryos, but also those who approve of this, apparently believe that the enhanced chance of a successful pregnancy and of fulfilling their wish for a child outweighs the moral value of each of the embryos. After all, they know beforehand that most of the created embryos will die, including some of "top quality".

\section{Intention/foresight distinction}

Defenders of DCD often justify the sacrifice of spare embryos by referring to the principle of double effect or to the "intention/foresight distinction". ${ }^{29}$ They say that the embryos in a fertility treatment are created for the purpose of procreation and that the existence of spare embryos and their "destruction" is merely a non-intended side effect. However, if we apply the principle of double effect to the issue of spare embryos, the non-intended side effect is "making spare embryos" and not "research on spare embryos" or "discarding spare embryos". Experimenting is merely a new action, which must be justified on another basis. $^{30}$

The basis on which defenders of DCD justify research on spare embryos is a consequentialist argument, namely that the respect we have with regard to the human embryo as a potential person has to be balanced against other values and needs, namely the development of therapies. Whether or not the primary intention was the creation of a baby is irrelevant. They are responsible for the foreseeable results of their actions. ${ }^{31}$

But is the deliberate "destruction" for research of thousands of spare embryos-with the same intrinsic status as any other embryo-commensurate with their moral status as a potential person?

Yes, if this moral status is seen as variable and dependent on people's intentions-for example, whether or not to include it in a parental project. Defenders of DCD apparently think that the potential of each created embryo to become a person should not be realised per se. Their protection can be weighed up against other values, such as the autonomy of the conceivers of the embryos who have to give their informed consent about the destination of their spare embryos (after all, an other option could be that each spare embryo should be adopted out).

Why cannot we then create embryos for stem cell research? After all, their intrinsic potential is also weighed up against other values and needs, namely the important research purposes.

\section{Creation of embryos for stem cells entails a different kind of exploitation}

Defenders of DCD defend their viewpoint by stating that the creation of embryos for stem cell research entails a "different kind of exploitation" because unlike a research embryo, a spare embryo has had a chance of becoming a person and we have therefore treated it with more respect than a research embryo. ${ }^{32}$ In their opinion, an embryo created for research is clearly being used merely as a means to an end, because it has no prospect of implantation, whereas at the time of creation the spare embryo had a prospect of implantation, even if, once not selected for implantation, it would have to be destroyed. ${ }^{33}$

Is this reasoning strong enough to justify DCD? Consider the following thought experiment: suppose we make research embryos, because it is the best way to reach the promising research goal. For the sake of argument, we might propose making a random selection of the same percentage of spare embryos that become a human from the research embryos and donate them to infertile couples who need a donor embryo. The percentage of "research embryos" that becomes a human would then be the same as that of the "spare embryos" that do so. Consequently, they would have had the same chance of becoming a person. ${ }^{34}$

If we would put this into practice, what results would we get? We know that about $3.5 \%{ }^{35}$ of the created embryos in an IVF treatment become a person. To be more correct we would need to donate more than $3.5 \%$ of the research embryos to infertile couples, since only a fraction implants and goes to term. Suppose we would donate $10 \%$ of the research embryos. In the UK, the creation of research embryos has been allowed since 1990. Human Fertilisation and Embryology Authority (HFEA) figures show that between 1991 and 2000, a total of 925747 embryos were created by IVF, of which only 118 were solely for research. ${ }^{36}$ Would defenders of DCD, bearing in their minds that in the same period 53497 spare embryos were donated for research and 294584 were destroyed, feel more comfortable if they knew we had donated 12 ( $10 \%$ of 118 ) of these research embryos to infertile couples for adoption?

What argument would supporters of DCD put forward against this proposal?

I think they would not have a strong argument. I think they even would not have a sound argument if we proposed to create research embryos and guarantee that one of them will become a person. After all, every embryo has had a chance of becoming a person and thus was treated as an end in itself. Without this proposal, none of them would have had a chance of existing at all. The survival chance of each embryo was not optimised because of other important values (helping ill and injured people). But this is also the case in IVF treatments, which put high risks on the embryos and 
decrease the intrinsic chances on survival of the embryos. (To protect women against multiple ovarian stimulation embryo sparing techniques are rarely used, and the freezing procedure puts high risk on embryos of good quality- $50 \%$ of good quality embryos do not survive this procedure.)

The idea of taking a certain percentage out of research embryos might sound a bit absurd, but it helps to show that, apparently, defenders of DCD think that it is not that important to realise the intrinsic potential of each deliberately created embryo. It seems inconsistent that defenders of DCD are offended by the idea of the creation of research embryos as to oppose it despite the enormous benefits of the research for millions of people, while at the same time doing so little to optimise the intrinsic potential of embryos and instrumentalise them in IVF and research practices.

Moreover, the fact that defenders of DCD so strongly reject the making of "research embryos" is rather astonishing. As we all know, the IVF technique, the method of cryopreservation, intracytoplasmic sperm injection (ICSI), and other techniques were all developed through research on embryos that only came into being for the purposes of the experiment. So defenders of DCD consider this type of experiment to be unacceptable from an ethical standpoint, although the results of such experiments are applied without any qualms and in most countries have even become routine. The same is true for embryo experiments that are currently done to develop methods to improve, facilitate, or make reproduction possible, such as the development of better methods of in vitro culture and IVF, and of gamete and embryo storage. ${ }^{37}$

\section{Embryos can only be instrumentalised for reproduction}

One possible reply of defenders of DCD is that in the case of embryo experimentation for the improvement of, for example, culture conditions or other IVF procedures, embryos are instrumentalised for reproductive purposes, and this is justified because it is the embryo's "function" to be used for reproduction. ${ }^{38}$ I think this argument is very weak, primarily because it does not take into account what is in the interest of the embryo (or of the person who will result from the embryo). If I were an embryo I would prefer to be in the lottery proposed by the thought experiment, to being used in "destructive" research to improve culture conditions in the context of an IVF treatment..$^{39}$ Moreover, the embryos are not always instrumentalised for reproductive purposes. They are also-and often solely-used as a means to other ends. Spare embryos are created to protect women undergoing fertility treatment against the risks of hormone treatment, and research embryos are used in investigations that aim at increasing safety and efficiency in freezing procedures.

\section{Harm/omit to benefit}

Another argument defenders of DCD use is that embryos can be instrumentalised for reproduction because it prevents harm to actual infertile women who undergo fertility treatments, while, in the case of stem cell research, embryos are sacrificed only for the benefit of unidentifiable people who might be benefited by stem cell therapy, but whom we do not harm now by not doing so. Infertile women will be made worse off than they would otherwise be, whereas sick people will be made better off than they would otherwise be. The underlying principle is that the obligation not to harm is stronger than the obligation to benefit. ${ }^{40}$ People who bring forward this argument, however, depart from the idea that infertile people will make use of fertility treatments anyhow. This paper, however, investigates the inconsistency between normative stands of defenders of DCD. Consequently, one has to depart from their beliefs and attitudes, namely the fact that they accept the creation and sacrifice of embryos to help infertile people-that is, for their benefit. After all, another option open for them is to oppose IVF treatments because embryos should not be created and sacrificed for these purposes. They would not harm these people; they would omit to benefit them. Their argument that embryos may not be instrumentalised for the benefit of people clearly fails. ${ }^{41}$ If defenders of DCD oppose the creation of embryos for stem cell research, they have to argue why it is more important to benefit people with a child-wish, than to benefit ill and injured people, and this to the extent that justifies the prohibition of the latter. I do not think they have a sound argument.

\section{A VIEW COMPATIBLE WITH THE BELIEFS OF DEFENDERS OF DCD AND WITH WIDELY SHARED VALUES}

I think that a view on ESCR that also accepts the creation of research embryos for stem cell derivation is compatible with the actual beliefs of those who now defend DCD. Defenders of DCD believe that an embryo merits special respect because of its intrinsic value, but that its potential to become a person can be weighed up against other values. There are forms of respect and deference which are less absolute and which can have gradations. The respect one has for an entity does not exclude it, provided that a meaningful argument is presented, from being used as a resource for a goal which is believed to be important. (Research on cadavers, with the informed consent of the party in question and on the condition of respectful treatment, is entirely legitimate in most countries.) Early embryos are respected by ensuring that they are used with care in research that incorporates substantive values such as the alleviation of human suffering (in accordance with the principles of beneficence and proportionality), by guaranteeing that their potential will not be wasted (in accordance with the principle of waste avoidance) and that they will only be used if there are no less contentious means of achieving the intended goal (in accordance with the subsidiarity principle). Well regulated stem cell research that uses embryos solely created for these purposes can be consistent with these widely shared values.

\section{CONCLUSION}

I have argued that whatever the basis is on which defenders of DCD accord intrinsic value to the embryo, once they accept the creation and sacrifice of embryos to benefit infertile people with a child-wish, they do not have a sound reason to condemn the creation and sacrifice of embryos to benefit ill and injured people who could be helped by stem cell therapies. If we consider the revealed beliefs of advocates of DCD, it seems that in general many people have respect and concern for some kind of protection for embryos, but that these feelings can change and depend on whether or not an embryo is involved in a parental project. In other words, the value they accord to the embryo is variable and depends also on criteria external to the embryo and related to intentions of people. Creating embryos for their stem cells is commensurate with the variable moral status defenders of DCD actually accord to the embryo, and, as is the case with spare embryos, these research embryos would be instrumentalised or exploited for the benefit of other people. An approach to ESCR that would also allow the creation of embryos solely for the derivation of stem cells would be compatible with the revealed beliefs of those who currently defend DCD, and with widely shared values, in particular the alleviation of individual human suffering.

\section{ACKNOWLEDGEMENTS}

I wish to thank $J$ Savulescu and $\mathrm{T}$ Takala for their helpful comments. 


\section{REFERENCES}

1 Kiessling AA, Anderson S. Human Embryonic Stem Cells. An Introduction to the Science and Therapeutic Potential. USA: Jones and Bartlett Publishers, Inc 2003: 164. Solter D, Beyleveld D, Friele MB, et al. Embryo Research in Pluralistic Europe. Berlin Heidelberg: Springer Verlag, 2003.

2 European Commission. European Commission Survey on Human Embryonic Stem Cell Research. Brussels: European Commission, 2003. Bosch X. Spain to allow human embryo research. Scientist 3 July 2003

3 See reference 1: Solter et al, 186-7.

4 This term is used in the report of the US National Bioethics Advisory Commission. Ethical Issues in Human Stem Cell Research. Rockville, MD: NBAC, 55. See also Green RM. The Human Embryo Research Debates. Bioethics in the Vortex of Controversy. New York: Oxford University Press, 2001

5 Some say that embryos resulting from nuclear transfer are not embryos and prefer to call them something else-for example, "ovasomes". Kiessling and Anderson. See reference 1: 62, The chair of ACT's ethical advisory board suggests the term "ovumsum". Anonymous. The meaning of life [opinion] Nature 2001:412:255.

6 See reference 1: Solter et al, 142. Heinemann T, Honnefelder L. Principles of ethical decision making regarding embryonic stem cell research in Germany. Bioethics 2002;16:530-43, ESHRE Taskforce on Ethics and Law. Stem cells. Hum Reprod 2002;17:1409-10.

7 Deutsche Forschungsgemeinschaft, New DFG Recommendations Concerning Research with Human Stem Cells. Press Release No. 16, 2001

8 The President's Council on Bioethics. Staff Working Paper. Monitoring Stem Cell Research: The Ethical Debates Reviewed. Washington, DC: PCB, October 2003.

9 See reference 4, National Bioethics Advisory Commission: iv. Commission of the European Communities. Commission Staff Working Paper: Report on Human Embryonic Stem Cell Research. Brussels: European Commission, 2003:9.

10 See reference 9: Commission of the European Communities, 34

11 See reference 4: National Bioethics Advisory Commission, 56.

12 Health Council of the Netherlands. Stem Cells for Tissue Repair; Research on Therapy Using Somatic and Embryonic Stem Cells. The Hague: Health Council of the Netherlands, 2002:46.

13 Harris J. The ethical use of human embryonic stem cells in research and therapy. In: Burley J, Harris J, eds. A Companion to Genethics: Philosophy and the Genetic Revolution. Oxford: Blackwell, 2002.

14 There are of course other reasons to allow the use and derivation of stem cells from spare embryos, such as regulatory scrutiny and economic reasons (See reference 1: Solter et al, 126, 153) but this paper only treats the ethical justifications underlying DCD

15 European Commission Research Directorate-General. Italian National Bioethics Document. In: Matthiessen L, ed. Survey on Opinions from National Ethics Committees or Similar Bodies, Public Debate and National Legislation in Relation to Human Embryonic Stem Cell Research and Use. Brussels: European Commission Research Directorate-General, 2003, Available from: www.europa.eu.int/comm/research/quality-of-life/stemcells/pdf/ overview en.pdf. See also Harris J. Stem cells, sex, and procreation. Camb Q Health Ethics 2003:12:360.

16 See reference 6: Heinemann T, Honnefelder L, 539.

17 FitzPatrick W. Surplus embryos, nonreproductive cloning, and the intend/ foresee distinction. Hastings Cent Rep 2003;33:29-36.

18 See reference 9: NBAC, 53

19 See reference 6: Heinemann T, Honnefelder L, 537-8.

20 See reference 6: ESHRE Taskforce on Ethics and Law.

21 We make use of spare embryos now without sliding down the slope. It is important to note that people already place embryos in a different mora category from persons. For a more extensive treatment of this issue see Persson I. Two claims about potential human beings. Bioethics 2003; 17:503-16, See reference 17.
22 Embryo Act. Section 5.2. Available from www.bioethics.gr/images/engembryowettekst.pdf.

23 See reference 12: 45

24 National Consultative Ethics Committee. Opinion on the Preliminary Draft Revision of the Law on Bioethics, Opinion No 67. Paris: CCNE, 2001.

25 I treat the different interpretations in Devolder K. Human embryonic stem cell research: why the discarded-created-distinction cannot be maintained on the basis of the potentiality argument. Bioethics 2005; (in press).

26 People Science \& Policy Ltd. Public Consultation on the Stem Cell Bank. London: People Science \& Policy Ltd, 2003:2, 11.

27 Trounson A. Human embryonic stem cells. Lectures in Medicine. Embryonic Stem cells. Faculty of Medicine and Pharmacy Brussels, 2003 [personal communication]. A study of infertile couples in Belgium shows that $92 \%$ of those who freeze embryos as part of their fertility treatment approve of the eventual destruction of their surplus embryos. Englert $Y$. The fate of supernumerary embryos: what do patients think about it, In: Hildt E, Mieth D, eds. In Vitro Fertilisation in the 1990s: Towards a Medical, Social and Ethical Evaluation, Aldershot: Ashgate, 1998:227-32. The findings of Australian studies show that fewer than $10 \%$ of the spare embryos are donated to infertile couples who need a donor embryo. Hammarberg K, Oke EK.The impact of changing legislation on couples with embryos frozen in excess of five years. Proceedings of the 16th Annual Meeting of the European Society for Human Reproduction and Embryology. Bologna, Italy, 2000. Kovacs GT, Breheny SA, Melinda JD. Embryo donation at an Australian university in-vitro fertilisation clinic: issues and outcomes. Med J Aust 2003;178:127-9. A recent survey shows that $57 \%$ of British couples undergoing IVF treatment at the Newcastle Fertility Centre said they would donate their "spare embryos" for stem cell research purposes. Anonymous. Many UK couples favour embryo stem cell donation. Bionews 6 January 2004. Available from: www.bionews.org.uk/ new. lasso? storyid $=1934$.

28 See reference 27: Hammarberg K, Oke EK, Abstract P-251

29 See reference 17: 30

30 See Devolder K. Making use of the cloning issue to prefigure the public debate on stem cell research. In: Lee SC, ed. Proceedings of the Third International Conference of Bioethics: Ethics, Legal and Social Issues in Human Pluri-potent Stem Cells Experimentation. Chungli, Taiwan ROC, 2001:N1-N16.

31 For this line of reasoning see also Harris J, reference 15

32 See reference 17: 29-30.

33 The House of Lords. Stem Cell Research Committee. Stem Cell Research. House of Lords: London, February 2002, Chapter 4, section 4.27.

34 For this thought experiment, see also Savulescu J. The embryonic stem cell lottery and the cannibalisation of human beings. Bioethics 2002;16:508-29, Harris J, reference 15, and Devolder K. The human embryonic stem cell debate: steered toward foregone principles and conclusions? Paper presented at the Sixth IAB World Congress of Bioethics. 30 October -3 November 2003, Brasilisa, Brazil. It will appear in Devolder K, reference 25.

35 In Belgium, 504 of the 14407 frozen spare embryos become humans -that is, $3.5 \%$. Devroey P. The fate of embryos in different cases. Symposium organised by the Special Interest Group on Ethics of ESHRE. Cryopreservation of Human Embryos. Brussels, AZ-VUB, 1999 [personal communication]. In the US around 90000 IVF cycles are performed each year, with around 30000 IVF babies born. See reference 1, 38 .

36 House of Commons Science and Technology Committee. Developments in Human Genetics and Embryology. Fourth Report of Session 2001-02. London: House of Commons, 18 July 2002: paragraph 18.

37 See reference 1: Solter et al, 45-52.

38 Thanks to J Savulescu for this suggestion.

39 See for this reasoning reference 34, Savulescu J.

40 Thanks to J Savulescu for this suggestion.

41 It is important to assess whether the approval of the instrumental use of preimplantation embryos for therapies implies the approval of pregnancy for abortion. I think it does. For an extensive treatment of this issue see Savulescu J. Should we clone human beings? Cloning as a source of tissue for transplantation. J Med Ethics 1999;25:87-95. 